\title{
LAND USE ANALYSIS USING TIME SERIES OF VEGETATION INDEX DERIVED FROM SATELLITE REMOTE SENSING IN BRANTAS RIVER WATERSHED, EAST JAVA, INDONESIA
}

\author{
K. Yoshino a, Y. Setiawan ${ }^{\text {b,d }}$, E. Shima ${ }^{c}$ \\ a Faculty of Engineering, Information and Systems, University of Tsukuba, 1-1-1 Tennoudai, Tsukuba, Ibaraki, 305-8573, Japan \\ ${ }^{b}$ Faculty of Forestry, Bogor Agricultural University, Kampus IPB Darmaga, Bogor 16680, Indonesia \\ c School of Veterinary Medicine, Kitasato University,23-35-1 Higashi, Towada, Aomori, 034-0005, Japan \\ ${ }^{d}$ Center for Environmental Research, Bogor Agricultural University, Kampus IPB Darmaga, Bogor, 16680, Indonesia
}

\section{Article Info:}

Received: 29 December 2016 in revised form: 7 April 2017

Accepted: 9 May 2017

Available Online: 30 October 2017

\section{Keywords:}

Time series dataset, Land use classification, MODIS vegetation index, Brantas watershed

\section{Corresponding Author:}

Kunihiko Yoshino

University of Tsukuba, 1-1-1

Tennoudai, Tsukuba, Ibaraki, 305

8573, Japan

Email: sky@sk.tsukuba.ac.jp

\begin{abstract}
In this study, time series datasets of MODIS EVI (Enhanced Vegetation Index) data from 2002 and 2011 in the Brantas River watershed located in eastern Java, Indonesia were analyzed and classified to make ten land use maps for each year, in order to support watershed land use planning which takes into account local land use and trends in land use change. These land use maps with eight types of main land use categories were examined. During the 10 years period, forested area has expanded, while upland, paddy rice field, mixed garden and plantation have decreased. One of the reasons for this land use change is ascribed to tree planting under the joint forest management system by local people and the state forest corporation.
\end{abstract} This open access article is distributed under a Creative Commons Attribution (CC-BY-NC-SA) 4.0 International license.

\section{How to cite (APA 6th Style):}

Yoshino, K., Setiawan, Y., \& Shima, E. (2017). Land Use Analysis using Time Series of Vegetation Index Derived from Satellite Remote Sensing in Brantas River Watershed, East Java, Indonesia. Geoplanning: Journal of Geomatics and Planning, 4(2), 109-120. doi:10.14710/geoplanning.4.2.109120

\section{INTRODUCTION}

The sustainability of regional environment and society has become an important issue due to the effects of global warming being recognized throughout the world (Parry et al., 2007). Regional land use is easily affected not only by global warming but also socio-economic development and population growth (Kaneko et al., 1998). On the other hands, land use itself affects global environment and regional-global climate (Foley et al., 2005). Examination of regional land use over a long period of time is useful to determine any changes in the natural environment and society and to understand the trends in these changes, causes and processes (Himiyama \& Okamoto, 1992).

In regions where large-scale irrigation development projects such as dams, irrigation canals and so on all over the world (JICA, 2011) have been carried out, the projects have affected both regional society and the natural environment, since infrastructure development induces socio-economic development, then urbanization begins in the region. Generally, urbanization affects both regional society and environment. Monitoring regional land use over a long period is helpful to study the sustainability of natural environment, society and development projects (Ramankutty \& Foley, 1999).

Water infrastructure in Indonesia had been developed since the Dutch Colonization period, in order to avoid floods and to build irrigation system. Many of the infrastructures for irrigation and drainage constructed by these projects have remained and are still in use and providing social services to the region (Pasandaran, 2007). These large-scale developing projects under some urban policies on regional development could actually have affected regional environment (Amato et al., 2016). Indonesia is a suitable area to study sustainable agricultural development and future land use against global climate change. That 
is how they can modify their regional development plans in future, because they have a very long history of regional development for longer than one hundred years, especially in the areas or watersheds where regional socio-economies have been rapidly growing. These areas are thought to be dramatically changing due to the expansion of urban areas or agricultural land development by increasing population. In these areas, the newly developed lands have been expanding following the land use plans of the local government and also by illegal development. In order to control this illegal development, the characteristics of regional land use patterns and their changing trends should be understood in order to propose some applicable land use plans for watersheds and also to have better sustainability of the global ecosystems and human beings (Foley et al., 2011).

Brantas watershed is the biggest watershed in East Java Province (BBWS Brantas, 2011). However, the local environmental agency indicated that vegetated lands in this watershed are under pressure, especially in upstream areas. Many existing land use allocations are inconsistent with spatial land use planning, even though the government rules, namely the Law No. 26/2007 on spatial planning and Law No. 41/2000 on basic forestry law, are stating that at least $30 \%$ of the area has to be allocated to vegetated land, such as garden and forest (BLH Prov. Jawa Timur, 2009). Based on these reports, it could be estimated that the agricultural lands or residential lands have disorderly invaded into the natural land use such as forest land. As a result, the forest environment has been degraded. The land use in this area could be intently changing to agricultural lands.

The objectives of this research were, 1) to create annual land use maps of the Brantas River watershed in eastern Java, Indonesia from 2002 to 2011 using time series MODIS EVI data applying a wavelet de-noise filter, and 2) to study the characteristics of regional land use patterns and trends in land use change. This paper contains five chapters. After mentioning the backgrounds of this research, data and methods used in this research are described in the chapter 2 . In the chapter 3 , the results of land use mapping for 10 years in Brantas watershed using time series MODIS EVI data are given. In the chapter 3, we also discuss about land use patterns in this area and land use change during these 10 years. Finally, in the chapter 4 , we conclude our findings resulted in this research.

\section{DATA AND METHODS}

\subsection{Study site}

Brantas River watershed located in the eastern part of Java, Indonesia (Figure 1) and has a tropical monsoon climate. The annual average air temperature from 1996-2000 and the annual average precipitation are 25.12 degrees Celsius and 1,876 mm/year, respectively (Widianto et al., 2010; WMO, 2013). Its area comprises approximately $12,000 \mathrm{~km}^{2}$ and Surabaya city is situated at the mouth of Brantas River, the second largest city in Indonesia with population of about 3 million. It is a famous agricultural area. Most of the land use types are: forest, plantation, mixed garden, rice paddy field, and uplands. Triple-rice cropping is undertaken in this watershed (Haruyama, Ooya, \& Mizuhara, 1992). Recently, the socioeconomic situation in this watershed has rapidly risen along with an increasing population (Bhat, Ramu, \& Kemper, 2005). Therefore, rational land use and sustainable environmental planning are necessary (JBIC Institute, 2008).

The downstream area of Brantas River has frequently suffered from flooding such as the large flood occurred in 2010. The flooding caused damage to crops, inability to cultivate land due to water logging of soils, disruption of settlement, transportation and loss of property. To counter these problems, many flood control projects have been carried out by the Indonesian government since the 1950's as well as other large scale flood control projects such as construction of big dams and irrigation-drainage projects under Japanese-aid (JICA, 2011). However, in spite of these projects and the forest management policy of Indonesia's government, floods have frequently occurred (Hidayat, 2009). In addition, dynamics changes of forest cover are found in forested areas (Setiawan, Yoshino, \& Prasetyo, 2014), and sedimentation on the river floor has become severe (Adi, Jänen, \& Jennerjahn, 2013; Widianto et al., 2010). It is therefore assumed that there are other reasons for frequent floods. The characteristics of land use patterns and the trends in land use change in this watershed should be understood in detail to facilitate rational watershed management and sustainable agricultural development. 


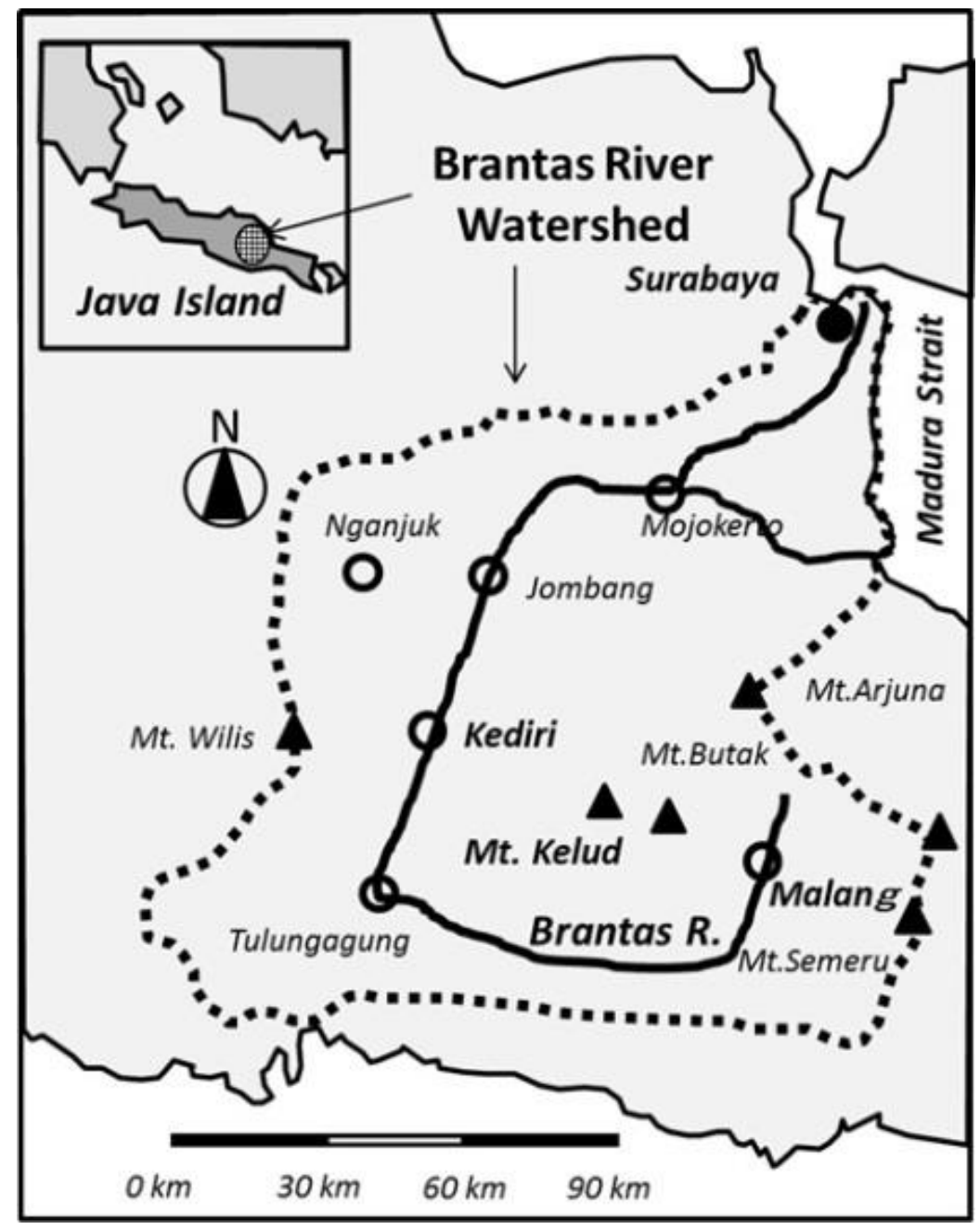

Figure 1. Outline map of Brantas River watershed

\subsection{Remotely sensed imagery in this study}

Monitoring land use precisely changes in large regions over a long period of time and to carry it out in detail is generally difficult. Recently, satellite optical remotely sensed images are used to study land use and land cover both on a global scale and in regional scale (Di Palma et al., 2016). However, there are some shortcomings in applying this method to tropical regions where the cloud coverage rate is high (Setiawan, Yoshino, \& Philpot, 2013). Time series MODIS (MODerate resolution Imaging Spectroradiometer) data recorded by two earth observation satellites, Terra and Aqua, are valid to obtain land use and land cover change over a global scale or regional scale (Friedl et al., 2002; Sakamoto et al., 2006). These two satellites observe the whole surface of the earth twice a day. Secondary MODIS datasets that were processed from observed data for specific purposes are open to the public and can be downloaded via the internet (LPDAAC, 2013a). These datasets provide information on the condition and dynamics of the earth surface such as land use/land cover in short time intervals.

The time series MODIS EVI (Enhanced Vegetation Index) produced from the observed data were used in this study. The datasets are referenced as H29V9 of MODIS Sinusoidal Tiling System (LPDAAC, 2013b) and cover the study site. The 230 scenes of MODIS EVI datasets, MYD13Q1 (LPDAAC, 2013d) observed from July 2002 to June 2012, a period of 10 years. The 16-days composite data with the spatial resolution of $250 \mathrm{~m}$ were downloaded from the NASA's web-site (NASA, 2013). These datasets comprising point data of MODIS original scenes for 16 days as the probability for cloudless observation of the ground is considered optimal during this time period. 
EVI is one of the vegetation indices developed by Huete et al. (2002). It was computed using band data from the visible blue band, visible red band and infra-red band. It reduced the effects of variation in the sun irradiance, thin cloud or cloud shadow, topographic effects, sun elevation and view-angle effects. Moreover, atmospheric effects such as scattering and absorption are removed as it uses visible blue band data. However, additional data processing is necessary, since datasets from tropical regions are affected by cloud noise (Solano, Didan, \& Jacobson, 2013).

\subsection{Procedures for data processing}

The 230 scenes of MODIS EVI 16-days composite datasets for the 10 years were aggregated and analyzed as follows. Every processing algorithm is standard and popular in order to analyze satellite remote sensing data.

[1] Reprojection of each image using MRT (LPDAAC, 2013c): an application was used for reprojection of datasets from the MODIS original projection system to WGS-84 geographical projection system. For computation of area of land use, images were reprojected to UTM coordinates system zone 49S and resampled at every $250 \mathrm{~m}$. At the same time, the QA (Quality assurance) of each dataset was validated.

[2] De-noising of the aggregated dataset: In order to remove the spike-like noises per pixel from the time series data in the aggregated dataset, a wavelet transformation filter was applied to the time sequential EVI of every pixel in the aggregated dataset using MATLAB wavelet tool (Mathworks, 2009), then a smooth time sequential EVI dataset was obtained. The wavelet model was the Coiflet model, the same model used by Sakamoto et al. (2006). The order 2 for the wavelet was applied in order to retain the original characteristics of the data. This de-noised time sequential data was divided into 10 datasets corresponding to each year.

[3] Supervised classification for land use mapping: The de-noised image of the base year was classified with a supervised classification algorithm using reference training data.

[4] Computation of correlation coefficients (Morita, 1985) between the base year dataset and the target year dataset: A pixel of each one-year dataset is a 23 dimensional vector. The correlation coefficients between pixels of the base year dataset and those of other one-year datasets were computed. The dataset from 2007 was retained as the base year dataset. Later, pixels which had higher correlation coefficients than 0.8 were chosen as training samples for supervised classification.

[5] Statistics of signature of each land use category were computed using the training samples chosen in previous step [4].

[6] Supervised classification for land use mapping: The algorithm of MLH (Maximum Likelihood) supervised classification was applied to map land use, and a land use map of each year was drawn.

[7] Characterization of trends: Using a land use map of each year, the characteristics of land use and the change in this watershed were analyzed and discussed.

\section{RESULTS AND DISCUSSION}

\subsection{Land use categories for classification and land use mapping of the base year}

Nineteen land use categories were determined (Table 1 ) by the previous work (Setiawan, Yoshino, \& Philpot, 2013). These 19 land use categories were those that could be selected as training data in this watershed. There were four categories of rice paddy fields, four of upland fields, one mixed garden, five of forest lands, three of plantations, one urban area, and one water surface. They are appropriate land use categories to study land use and land use change in this watershed. Totally 13,723 pixels were selected as the training samples. The de-noised image of the base year, a dataset from 2007, was classified with a supervised classification algorithm using these training data. This land use map in 2007 is used as a base or reference land use map for analysis of datasets of other years. The reason of 2007's dataset selection for creating a base land use map in this study is that a reliable land use map was drawn using satellite images taken in this year (Department of Forestry, 2008). 
Table 1. Reclassification of land use categories in this study (analysis, 2015)

\begin{tabular}{|c|c|c|}
\hline & $\begin{array}{c}\text { Land use category } \\
\text { (Setiawan et al., 2013) }\end{array}$ & Re-classed land use category \\
\hline 1. & Triple irrigated paddy field & 1. Triple crop paddy \\
\hline 2. & Double irrigated paddy field I & \multirow[t]{3}{*}{ 2. Double crop paddy } \\
\hline 3. & Double irrigated paddy field II & \\
\hline 4. & Double irrigated paddy field III & \\
\hline 5. & Upland & \multirow[t]{4}{*}{ 3. Upland } \\
\hline 6. & Upland with intensive agricultural land & \\
\hline 7. & Upland with mixed agricultural land & \\
\hline 8. & Irrigated fields & \\
\hline 9. & Mixed garden with bush & 4. Mixed garden \\
\hline 10. & Forest mixed with bush & \multirow[t]{5}{*}{ 5. Forest } \\
\hline 11. & Bush mixed grass & \\
\hline 12. & Dryland forest & \\
\hline 13. & Heterogeneous mangrove forest & \\
\hline 14. & Mangrove & \\
\hline 15. & Rubber plantation & \multirow[t]{3}{*}{ 6. Plantation } \\
\hline 16. & Oil palm plantation & \\
\hline 17. & Timber forest plantation & \\
\hline 18. & Builtup & 7. Urban area \\
\hline 19. & Pond & 8. Water surface \\
\hline
\end{tabular}

In order to provide a consistent definition for pixel based analysis, we need to resolve the differences among the nineteen land use categories in the dataset. The process of reassigning land use categories based on the knowledge of the each land use characteristic is shown in Table 1. Nineteen land use categories were re-classed into eight categories: triple cropping rice paddy field, double cropping rice paddy field, upland field, mixed garden, forest, plantation, urban area, and water surface. When tabulating an error matrix for evaluation of classification (Richards, 2006), it was found the overall classification accuracy was $71 \%$ for these 8 categories. In consideration of the spatial resolution $(250 \mathrm{~m})$ used on this dataset, this land use map is assumed to show a true land use pattern in this watershed around 2007.

\subsection{Sampling training data based on the correlation coefficients}

In general, strictly selected reference data should be used for supervised classification. Usually, samples are selected by designating several pixels which are thought to be proper training areas of each land use category with several ways such as ground survey, referring reliable land use maps in order to obtain sufficient number of training samples (Oobayasi \& Kojima, 2002). However, it is important to collect fine training data for every image to detect land use change in short periods from the results of land use classification in every year.

In this study, training samples were collected by selecting pixels which have higher correlation coefficients than 0.8 between the base year dataset of 2007. The other year datasets where those pixels have the same land use categories as the pixels in the base-year dataset were equally used, because only in 2007, we have a reliable land use map authorized by the Ministry of Forestry of Indonesia. For accessing the similarity of two spectral signatures which are recognized as two vectors of multiple variables, the angle between two vectors is observed as the similarity of two vectors. The smaller angle means that they have high similarity.

The value of COSIN of that angle is equal to the correlation coefficients in terms of the fundamental relationship between geometry and statistics. So, in this research, the correlation coefficients are used to measure the similarity of two vectors of the same pixels of two years. Figure 2 shows the accumulated frequency in percent of the correlation coefficients between each year and the base year dataset of 2007. Although the correlation coefficients of 2010 looks different from those of the other years, over 30 to $45 \%$ 
of pixels in the other year datasets have correlation coefficients higher than 0.8 . Thus, at least over 100 pixels were selected as training samples for each land use category in each year.

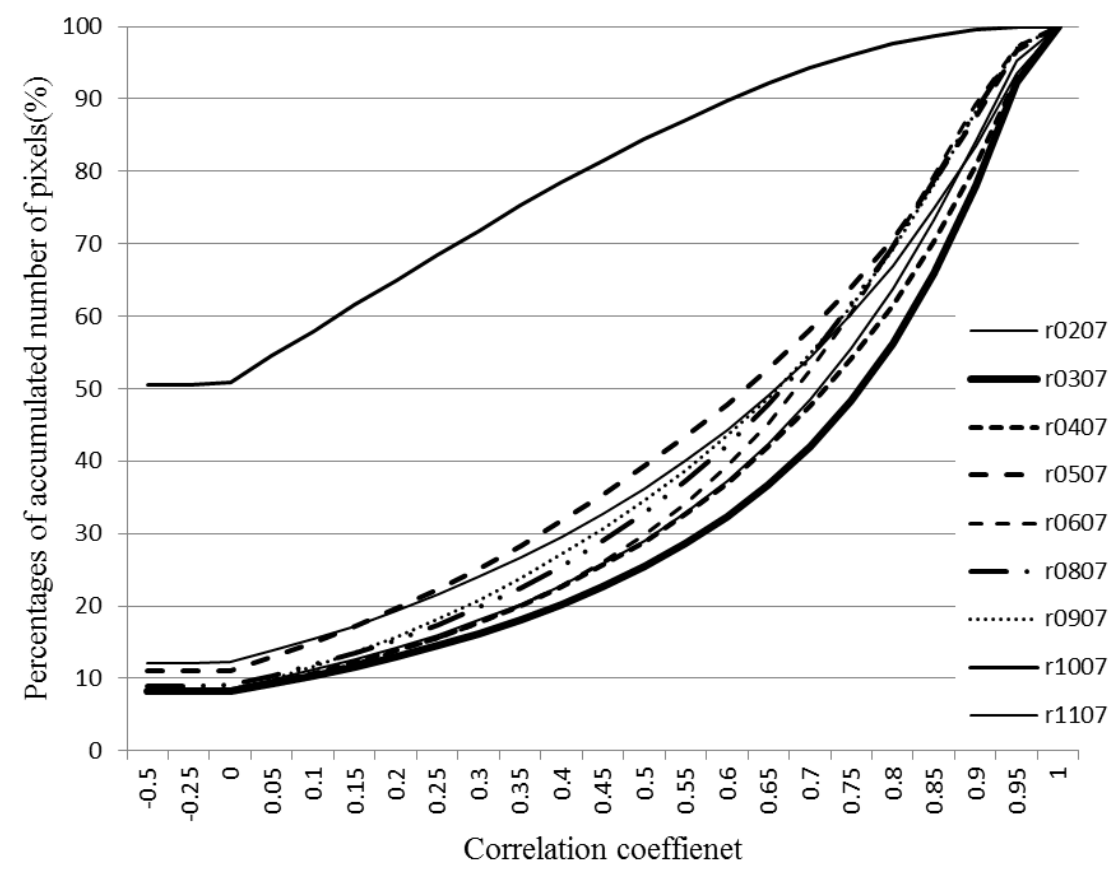

Figure 2. Accumulated histogram of correlation coefficients (the first 2 digit number in the legend shows the year of interest)

\subsection{Supervised classification result}

Supervised classification of land use for each year dataset except the dataset of 2007 was conducted with MLH (Maximum Likelihood method) using training samples selected in the former section. As example, the land use classification maps for 2002 and 2011 are shown in Figure 3. In these two land use maps, it is clear that land use in this area has been changed in many places.

In general, rice paddy fields widely spread downstream from Kediri and the mountains are covered with forest. Most lands except rice paddy fields and forest are upland field, mixed garden and plantation. In the coastal area of the eastern part of Surabaya, large fish ponds are expanding. However, they were classified into water surface.

\subsection{Land use change from 2002 to 2011}

The acreages of each land use category in each year from 2002 to 2011 are shown in $\mathrm{km}^{2}$, to study the trends of land use change in Brantas River watershed (Figure 4). Variations of acreages in each year are rather large for many land use categories. One of the causes of these large variations of estimated acreages of land use classes is assumed to be attributed to the intrinsic drawback of MODIS composite products. A pixel value is affected by the viewing geometry of MODIS sensor of observation dates which changes the dimension of the pixel on the ground, so that a pixel consists of spectral signals from ground cover conditions or land use of surrounding pixels. This intrinsic drawback leads a fairly large number of misclassification of MODIS composite data (Tan et al., 2006). As this drawback cannot be compensated, we will ignore the uncertainty of classification results in this paper.

Moreover, the previous study in East Java (Muhammad et al., 2016) also mentioned that the mixed pixel issue was an important consideration of land use classification using MODIS data since the classification result of specific land use classes revealed the overall accuracy to be $57.7 \%$. 
Apparently, the forest increased during the past 10 years, while other land use categories such as double cropping rice paddy, upland, mixed garden, and plantation seem to decrease. Water surface, triple cropping rice paddy field and urban area maintained their acreages.

The five years average acreage for each land use category from 2002 to 2006 was compared to those from 2007 to 2011 to summarize the trends of land use changes during the ten years period. As for forest, upland field and single cropping rice paddy field, they have increased to 718,48 and $5 \mathrm{~km}^{2}$ in acreage, respectively. By contrast, double cropping rice paddy field, triple cropping paddy field, mixed garden, plantation and urban area have decreased to $345,130,124,112$, and $59 \mathrm{~km}^{2}$, respectively.

Land use categories such as forest, upland field and double cropping rice paddy field showed a rapid change in their acreage on a scale of several tens thousands hectares since 2009 compared to other years. Forest area has increased, on the other hand, upland field and double cropping rice paddy field have decreased. The total annual precipitation of 2,483 $\mathrm{mm}$ and 2,274 mm during the period from July, 2009 to June, 2010 and during the period from July 2010 to June, 2011 in Surabaya area, respectively, was the reason of this change. These heavy rainfalls were recorded at the Surabaya meteorological observation station in this period. They were calculated based on precipitation records. These precipitation exceeded the 30 year average annual precipitation of $1,876 \mathrm{~mm}$ (WMO, 2013). Due to the natural physiological response of tropical plants against sufficient rainfall, vegetation in this area consequently grew further between 2009 and 2010 than in other periods, so that the annual EVI patterns in this period are understood to show different patterns from those of other periods.
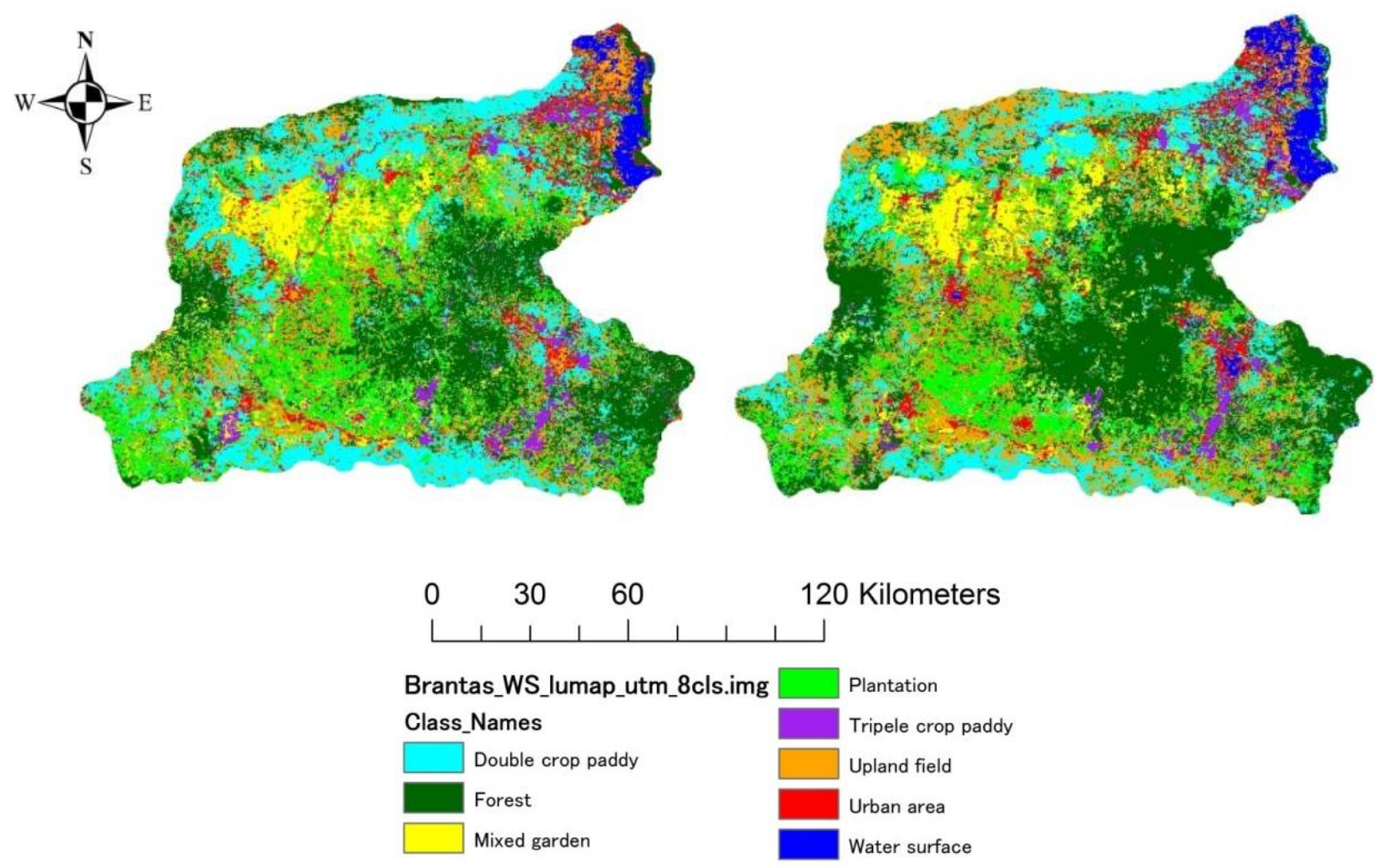

Figure 3. Eight categories land use maps in 2002 (left) and 2011 (right) 


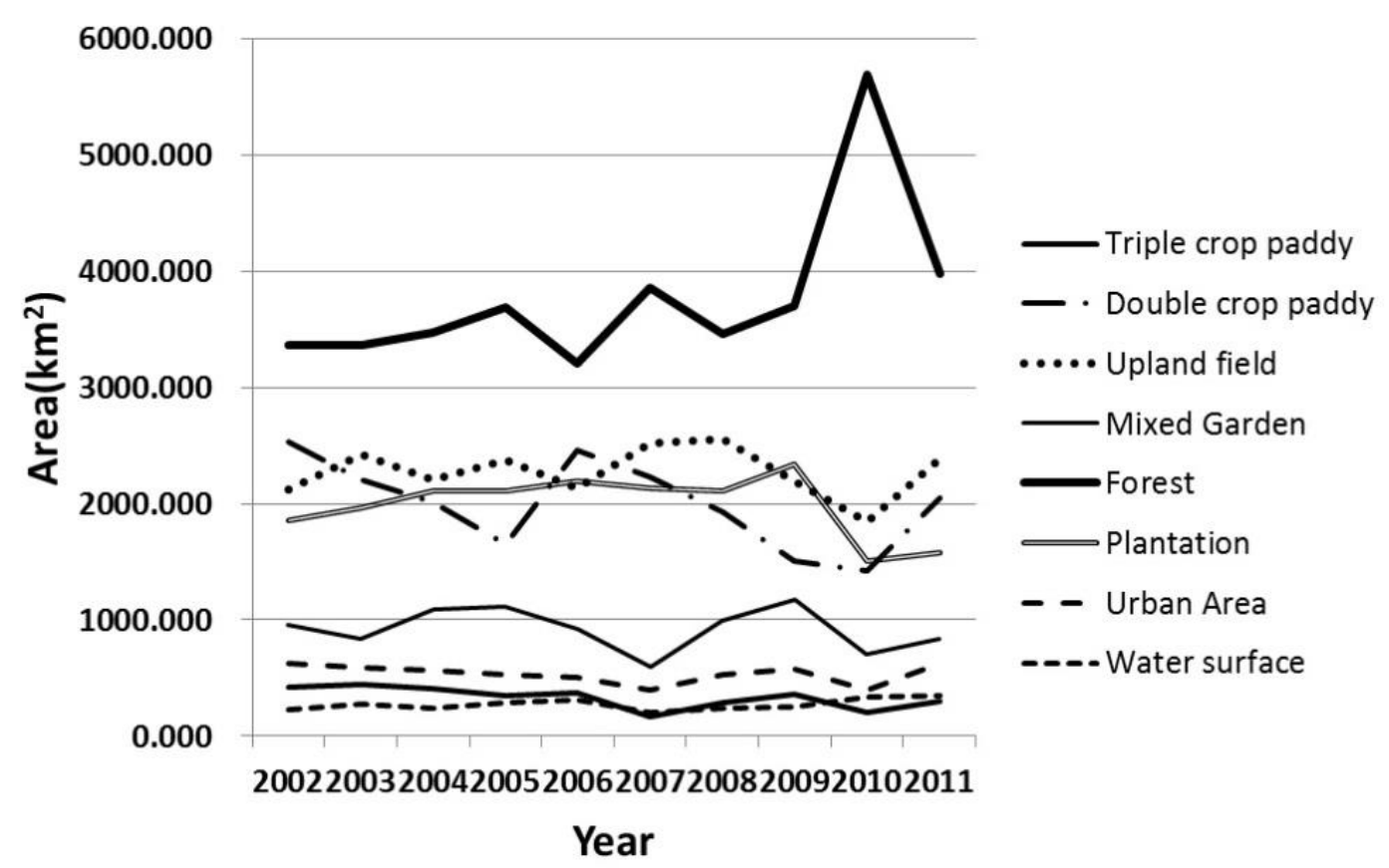

Figure 4. Land use change in Brantas River watershed 2002-2011

\subsection{Characteristics of land use change in the watershed}

\subsubsection{Land use change matrix}

Table 2 tabulated the land use change matrix between 2002 and 2011. The rows are the acreage for each land use in 2002, while the columns are those from $2011 \mathrm{in} \mathrm{km}^{2}$. The values in the diagonal items are unchanged acreages of the same land use categories both in 2002 and 2011 . The other items indicate the land use changes from 2002 to 2011. In this table, the conversion of land use from 2002 to 2011 focused on changes more than one hundred $\mathrm{km}^{2} ; 110 \mathrm{~km}^{2}$ of triple cropping rice paddy field changed to forest, $490 \mathrm{~km}^{2}$ of double cropping rice paddy field changed to upland, $457 \mathrm{~km}^{2}$ to forest, $151 \mathrm{~km}^{2}$ to plantation and 107 $\mathrm{km}^{2}$ to urban area.

About $498 \mathrm{~km}^{2}$ of upland have changed to forest, $321 \mathrm{~km}^{2}$ to plantation, $236 \mathrm{~km}^{2}$ to double cropping rice paddy, and $132 \mathrm{~km}^{2}$ to urban area. Meanwhile, $189 \mathrm{~km}^{2}$ of mixed garden have been converted into forest, $142 \mathrm{~km}^{2}$ into plantation, $306 \mathrm{~km}^{2}$ into upland, respectively. Then, $478 \mathrm{~km}^{2}$ of forest have been converted into upland, $311 \mathrm{~km}^{2}$ into plantation, $306 \mathrm{~km}^{2}$ into double cropping rice paddy field, $577 \mathrm{~km}^{2}$ of plantation into forest, $391 \mathrm{~km}^{2}$ into upland, $124 \mathrm{~km}^{2}$ into mixed garden, $94 \mathrm{~km}^{2}$ into double cropping rice paddy field, $85 \mathrm{~km}^{2}$ into forest. Moreover, $17 \mathrm{~km}^{2}$ of water surface have changed to upland, $10 \mathrm{~km}^{2}$ to double cropping rice paddy field, $12 \mathrm{~km}^{2}$ to urban area.

\subsubsection{Long term land use change}

In order to assess the long term stability of land use from 2002 to 2011, the unchanged land use of every land use category was examined by computing the acreages that did not change between 2002 and 2011 for each land use category (See the last line of Table 2). The total acreage of unchanged lands in 8 land use categories was about $872 \mathrm{~km}^{2}$. Other lands have temporally or almost permanently changed to other land use. About $219 \mathrm{~km}^{2}$ of rice paddy field, $477 \mathrm{~km}^{2}$ of forest, $54 \mathrm{~km}^{2}$ of mixed garden, $84 \mathrm{~km}^{2}$ of water surface, $9 \mathrm{~km}^{2}$ of upland field, $13.1 \mathrm{~km}^{2}$ of plantation and $15.8 \mathrm{~km}^{2}$ of urban area respectively have not changed. 
Forest distributed on the hillside of Mt. Kelud was unchanged. Unchanged rice paddy fields are seen in flat plain downstream of the Brantas River. Unchanged mixed garden is expanding in the suburban area near Kediri town. Unchanged water surface remains in the tidal area in the river mouth of the Brantas River. Unchanged triple cropping rice paddy fields are recognized upstream of the Brantas River. The unchanged urban area and upland fields are scattered. They are not spatially accumulated.

Table 2. Land use change matrix between 2002 and 2011

\begin{tabular}{|c|c|c|c|c|c|c|c|c|c|}
\hline \multirow{2}{*}{$\begin{array}{l}\text { Land use in } \\
2002\end{array}$} & \multicolumn{9}{|c|}{ Land use in 2011} \\
\hline & $\begin{array}{l}\text { Triple crop } \\
\text { paddy }\end{array}$ & $\begin{array}{l}\text { Double crop } \\
\text { paddy }\end{array}$ & $\begin{array}{l}\text { Upland } \\
\text { field }\end{array}$ & $\begin{array}{l}\text { Mixed } \\
\text { garden }\end{array}$ & Forest & Plantation & $\begin{array}{l}\text { Urban } \\
\text { area }\end{array}$ & $\begin{array}{l}\text { Water } \\
\text { surface }\end{array}$ & Total \\
\hline $\begin{array}{l}\text { Triple crop } \\
\text { paddy }\end{array}$ & 139.7 & 62.1 & 40.2 & 21.3 & 110.7 & 15.3 & 21.6 & 0.1 & 411.0 \\
\hline $\begin{array}{l}\text { Double } \\
\text { crop paddy }\end{array}$ & 46.9 & 1153.4 & 490.8 & 96.1 & 456.6 & 150.9 & 106.5 & 6.4 & 2507.6 \\
\hline $\begin{array}{c}\text { Upland } \\
\text { field }\end{array}$ & 21.1 & 235.8 & 721.6 & 69.0 & 498.1 & 320.5 & 131.9 & 91.4 & 2089.3 \\
\hline $\begin{array}{l}\text { Mixed } \\
\text { garden }\end{array}$ & 14.3 & 61.3 & 101.7 & 417.0 & 188.6 & 142.1 & 10.9 & 0.1 & 936.0 \\
\hline Forest & 57.6 & 306.3 & 477.6 & 88.9 & 2017.3 & 311.1 & 53.4 & 20.4 & 3332.6 \\
\hline Plantation & 9.1 & 107.1 & 391.2 & 123.8 & 577.1 & 601.4 & 26.9 & 0.3 & 1836.9 \\
\hline Urban area & 7.2 & 93.3 & 116.8 & 4.2 & 85.3 & 19.4 & 251.3 & 37.8 & 615.3 \\
\hline $\begin{array}{l}\text { Water } \\
\text { surface }\end{array}$ & 0.1 & 9.8 & 16.7 & 0.0 & 6.0 & 0.2 & 12.0 & 184.9 & 229.6 \\
\hline Total & 296.1 & 2028.9 & 2356.4 & 820.3 & 3939.6 & 1561.0 & 614.6 & 341.4 & 11958.3 \\
\hline Unchanged & 30.8 & 188.0 & 9.1 & 54.3 & 477.1 & 13.1 & 15.8 & 83.8 & 871.9 \\
\hline
\end{tabular}

\subsection{Driving forces of land use change}

According to the results of land use classification in this study, forest has increased its acreage between the first 5 years and the last 5 years. Furthermore, rice paddy field, upland field, mixed garden and plantation have decreased their acreages $100 \mathrm{~km}^{2}$ to several $100 \mathrm{sm}^{2}$. These results are contrary to expectation which was described in the introduction. As for the increase of forest, it is assumed that afforestation projects conducted by community based forest management system (CBFM) under the forest management system promoted by Perhutani Indonesia are working well to conserve the forest environment (Asia Forest Network, 2004). The fact that forest in this area has been steadily increasing indicates that the regional environmental policies in this watershed have begun to show their effects to regulate land use pattern and to mitigate the imprudent land development (Amato et al., 2016). Since the increase of forest in the hillside reduces the surface soil loss rates from the sparsely vegetated lands to the river, soil suspension of the river water could get lower, then, the sedimentation on the river floor in the river streams would decline (Yoshino \& Ishioka, 2005). Consequently, the frequency and the severalty of flooding of Brantas River will decrease in the near future.

Additionally, contrary to our expectation that the forest lands have intently decreased, the urban area did not significantly expand during the 10 years. One possible reason for this is that the spatial resolution of MODIS EVI, which is $250 \mathrm{~m} \times 250 \mathrm{~m}$, is too large to detect urban change. The small changes in urban area could be buried in this large spatial resolution of MODIS data. In order to detect area and location of such kinds of small scale land use changes in nearly real time, it is better to use the satellite images with higher spatial resolution. Plus, land use classification accuracies in this study are problematic. The highest overall accuracy was about $71 \%$ in 2007 , while in other years, they were at most $50 \%$. Setiawan, Yoshino, \& Philpot (2013) reported that over $40 \%$ of pixels from MODIS EVI data are mixed pixels that contain several land uses. The low spatial resolution of MODIS EVI dataset and temporal composite dataset of MODIS data 
products mainly resulted in the low land use classification accuracy (Campagnolo et al., 2016; Tan et al., 2006), although the satellites mounting MODIS sensors daily and observing the terrestrial surface and the remote sensed images are supposed to be useful to monitor temporal environmental changes of the earth. For detecting tiny land use changes over a wide extent of over several 100 's $\mathrm{km}$, datasets of high spatial and low temporal resolution are more suitable for analysis, although some troublesome problems remain to be solved. Actually, the answers to these problems depend on the research objectives.

\section{CONCLUSION}

Comprehensive land use planning based on long term monitoring of watershed is necessary in developing countries. This research selected the Brantas River watershed in eastern Java, Indonesia as a study area and analyzed land use change from 2002 to 2011 using a time sequential MODIS EVI dataset.

The results of this study were as follows: 1 ) during the 10 year period, forest had a tendency to increase acreage, while other land use categories, especially arable lands have decreased, 2) only $872 \mathrm{~km}^{2}$ of land remained unchanged in this watershed during these ten years, 3) examination of a land use change matrix between 2002 and 2011 clarified many types of land conversion, 4) afforestation projects conducted by local people promoted under the policy of Perhutani Indonesia could be one of the causes of land use changes in this watershed.

Lastly, the overall accuracies of classification were not highly adequate to deal with land use change in detail. Congalton (1991) reported that over $85 \%$ to $90 \%$ of overall accuracy of land use classification was necessary to study land use change. A much higher classification accuracy to detect tiny land use changes was indispensable. The following future works are essential to obtain more detailed results on land use and land use changes in this area: a) The determination of timing of land use changes, locations and driving forces for these changes, b) Analysis of the temporally trajectories of land use change and cycles of land use which seen in rice paddy fields or in traditional shifting cultivation, c) Research on optimal watershed management policy for the sustainable watershed ecosystem.

\section{ACKNOWLEDGMENTS}

This research was financially supported by research grand-aid of JSPS (Overseas research project 22402033) from 2010 to 2012. We very much appreciate anonymous reviewers for their very helpful comments and suggestions to improve our manuscript.

\section{REFERENCES}

Adi, S., Jänen, I., \& Jennerjahn, T. C. (2013). History of development and attendant environmental changes in the Brantas River Basin, Java, Indonesia, since 1970. Asian Journal of Water, Environment and Pollution, 10(1), 5-15.

Amato, F., et. al. (2016). The effects of urban policies on the development of urban areas. Sustainability, 8(4), 297. [Crossref]

Asia Forest Network. (2004). Communities Transforming forestland, Java, Indonesia.

BBWS Brantas. (2011). Balai Besar Wilayah Sungai Brantas Edisi 2011. Directorate General of Water Resources. Ministry of Public Works and Housing, Republic of Indonesia.

Bhat, A., Ramu, K., \& Kemper, K. (2005). Institutional and policy analysis of river basin management -The Brantas River Basin, East Java, Indonesia. World Bank Policy Research Working Paper 3611, May 2005.

BLH Prov. Jawa Timur. (2009). Land cover change in Brantas watershed for year 2000-2008.

Campagnolo, M. L., Sun, Q., Liu, Y., Schaaf, C., Wang, Z., \& Román, M. O. (2016). Estimating the effective spatial resolution of the operational BRDF, albedo, and nadir reflectance products from MODIS and VIIRS. Remote Sensing of Environment, 175, 52-64. [Crossref]

Congalton, R. G. (1991). A review of assessing the accuracy of classifications of remotely sensed data. Remote Sensing of Environment, 37(1), 35-46. [Crossref] 
Department of Forestry. (2008). Recalculation of Land Cover in Indonesia 2008. The Agency of Forestry Planning, Department of Forestry, Republic of Indonesia.

Di Palma, F., et. al. (2016). A SMAP Supervised Classification of Landsat Images for Urban Sprawl Evaluation. ISPRS International Journal of Geo-Information, 5(7), 109. [Crossref]

Foley, J. A., et. al. (2005). Global consequences of land use. Science, 309(5734), 570-574. [Crossref]

Foley, J. A., et. al. (2011). Solutions for a cultivated planet. Nature, 478(7369), 337-342. [Crossref]

Friedl, M. A., et. al. (2002). Global land cover mapping from MODIS: algorithms and early results. Remote Sensing of Environment, 83(1), 287-302. [Crossref]

Haruyama, S., Ooya, M., \& Mizuhara, Y. (1992). Development and conservation of rivers in active volcane zones -case study of Brantas watershed in the eastern Java, Indonesia. Journal of Geography, 101(2), 89-106.

Hidayat, F. (2009). Floods and climate change--Observations from Java. CRBOM Small Publicafions.

Himiyama, Y., \& Okamoto, J. (1992). Land use change and causes. Committee of agricultural policy survey, Tokyo.

Huete, A., et. al. (2002). Overview of the radiometric and biophysical performance of the MODIS vegetation indices. Remote Sensing of Environment, 83(1-2), 195-213. [Crossref]

JBIC Institute. (2008). Aid Effectiveness to Infrastructure: A Comparative Study of East Asia and Sub-Saharan Africa: Case Studies of East Asia. JBICI Research Paper No.36-2.

JICA. (2011). History-Goods for the future generation-The engineers spirits cultivated by one river. JICA's World, Special topic.

Kaneko, K., et al. (1998). Iwanami Kouza, Global environment. Sustainable Social Systems, 10.

LPDAAC. (2013a). MODIS. Retrieved from https://Ipdaac.usgs.gov/products/modis_products_table.htm

LPDAAC. (2013b). MODIS Overview. Retrieved from https://Ipdaac.usgs.gov/products/modis_overview

LPDAAC. (2013c). MODIS Reprojection Tool. https://lpdaac.usgs.gov/tools/modis_reprojection_tool.htm

LPDAAC. (2013d). Vegetation Indices 16-Day L3 Global. Retrieved from https://lpdaac.usgs.gov/products/modis_products_table/myd13q1

Mathworks. (2009). Matlab Online Documentation. Tech. Rep. The Mathemowrks, Inc.

Morita, Y. (1985). Introduction to new statistics. Nihon-hyouronn Inc., Tokyo.

Muhammad, M., et al. (2016). Analysis of the dynamics pattern of paddy field utilization using MODIS image in East Java. Procedia Environmental Sciences, 33, 44-53. [Crossref]

NASA. (2013). Reverb/ECHO. Retrieved from http://reverb.echo.nasa.gov/reverb/

Oobayasi, N., \& Kojima, N. (2002). Remote Sensing for strategists. Tokyo: Fuji Tecnosis System.

Parry, M. L., et al. (2007). Contribution of Working Group II to the Fourth Assessment Report of the Intergovernmental Panel on Climate Change. Cambridge University Press.

Pasandaran, E. (2007). Management of Infrastructure irrigation in national food security framework. Analisis Kebijakan Pertanian, 5(2), 126-149.

Ramankutty, N., \& Foley, J. A. (1999). Estimating historical changes in global land cover: Croplands from 1700 to 1992. Global Biogeochemical Cycles, 13(4), 997-1027. [Crossref]

Richards, J. (2006). Remote Sensing Digital Image Analysis. https://doi.org/10.1007/978-3-642-30062-2

Sakamoto, T., et al. (2006). Spatio--temporal distribution of rice phenology and cropping systems in the Mekong Delta with special reference to the seasonal water flow of the Mekong and Bassac rivers. Remote Sensing of Environment, 100(1), 1-16. [Crossref]

Setiawan, Y., Yoshino, K., \& Philpot, W. D. (2013). Characterizing temporal vegetation dynamics of land use in regional scale of Java Island, Indonesia. Journal of Land Use Science, 8(1), 1-30. [Crossref]

Setiawan, Y., Yoshino, K., \& Prasetyo, L. B. (2014). Characterizing the dynamics change of vegetation cover on tropical forestlands using $250 \mathrm{~m}$ multi-temporal MODIS EVI. International Journal of Applied Earth Observation and Geoinformation, 26, 132-144. [Crossref]

Solano, R., Didan, K., \& Jacobson, A. (2013). MODIS Vegetation Index user's Guide version 2.00. Retrieved from http://vip.arizona.edu/documents/MODIS/MODIS_VI_Users Guide_01_2012.pdf

Tan, B., et al. (2006). The impact of gridding artifacts on the local spatial properties of MODIS data: Implications for validation, compositing, and band-to-band registration across resolutions. Remote Sensing of Environment, 105(2), 98-114. [Crossref]

Widianto, W., Suprayogo, D., Sudarto, S., \& Lestariningsih, I. D. (2010). Implementasi Kaji Cepat Hidrologi (RHA) di Hulu DAS Brantas, Jawa Timur. Working Paper World Agroforestry Centre, 121. 
WMO. (2013). World Weather Information Services. Retrieved from http://www.worldweather.org/043 /c00648.htm

Yoshino, K., \& Ishioka, Y. (2005). Guidelines for soil conservation towards integrated basin management for sustainable development: a new approach based on the assessment of soil loss risk using remote sensing and GIS. Paddy and Water Environment, 3(4), 235-247. [Crossref] 